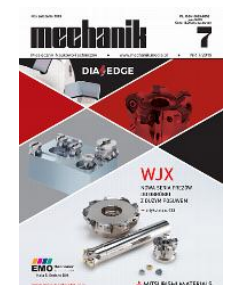

How to cite this article:

Author: Dariusz Kalwasiński

Title of article: „Computer software of virtual overhead crane simulator”

Mechanik, No. 7 (2019)

DOI: https://doi.org/10.17814/mechanik.2019.7.51

\title{
Computer software of virtual overhead crane simulator
}

\section{DARIUSZ KALWASIŃSKI *}

\author{
Mgr inż. Dariusz Kalwasiński, dakal@ciop.pl, https://orcid.org/0000-0002-1176-6998 - Centralny Instytut Ochrony Pracy - Państwowy \\ Instytut Badawczy, Zakład Techniki Bezpieczeństwa, Pracownia Technik Rzeczywistości Wirtualnej, Warszawa, Polska
}

The article presents the most important elements of a new computer software functioning in a modified overhead crane simulator. The article briefly defines the ways of communication between the overhead crane simulator's user and the overhead crane objects and display of images from the virtual environment. The software hereby presented is a crucial element of the modified simulator, as it impacts realism and fluency of the simulation process conducted by the user of the simulator.

KEYWORDS: mobile simulator, overhead crane, computer software

\section{Introduction}

Simulators cannot fully replace traditional practical training on real machines, they can only support this process. Literature data $[1,2]$ and own experience $[3,4]$ show that supporting a training with a simulator not only affects the attractiveness of training, but also shortens its time and reduces the costs (especially when real machines are used in the training). It also allows the operator to quickly master the skills of operating a given machine (stationary, portable or mobile) without worrying about its destruction. An additional benefit is the ability to simulate dangerous dynamic phenomena such as loss of load, impact with a load on an environment object, etc. This type of exercise cannot be carried out in real conditions due to safety requirements.

The paper is a continuation of work on the modification of the virtual crane simulator, which was developed in CIOP-PIB $[4,6]$ in the laboratory version. The simulator is based on the virtual reality (VR) technique, which allows the user (trainee) to be immersed in a virtual environment.

In the laboratory version, the simulator consists of:

- virtual environment computer application,

- seats for the simulator user,

- two control panels to control the virtual crane,

- VR equipment (VR goggles and stationary user's motion tracking system with motion sensors).

Actions presented include modification of the crane simulator software. Its most important elements and ways of user communication with this software were discussed. Great emphasis was placed on software modification, as it is an important element of the simulator. It depends on the realism and smoothness of the simulation after immersion in a virtual environment (e.g. using VR goggles).

\section{Crane simulator software}

Before attempting to modify the software, several tests were carried out to verify the process of simulating the use of a virtual crane. During the tests, attention was paid to:

- smooth simulation (i.e. objects moving in a virtual environment),

- smoothness of the image displayed in VR goggles,

- accident events initiated in a virtual environment.

Consultations were also carried out with instructors training future crane operators and with crane operators themselves. Consultations allowed to set expectations for the simulator and its software.

Many changes have been proposed that affect the compatibility of the virtual crane operation simulation process with the actual process and the crane operator training program. These changes included: 
- ability to display the environment on screens, not just in VR goggles,

- increasing the realism of the environment so that the displayed image is clearer,

- sharpening the shapes of environmental objects, especially those in close proximity to the crane operator.

For these reasons, as part of the work on modifying the simulator, new computer software was prepared, presenting a virtual environment in the form of a production and warehouse hall (fig. 1b), in which the crane operation simulation process is carried out.

a)

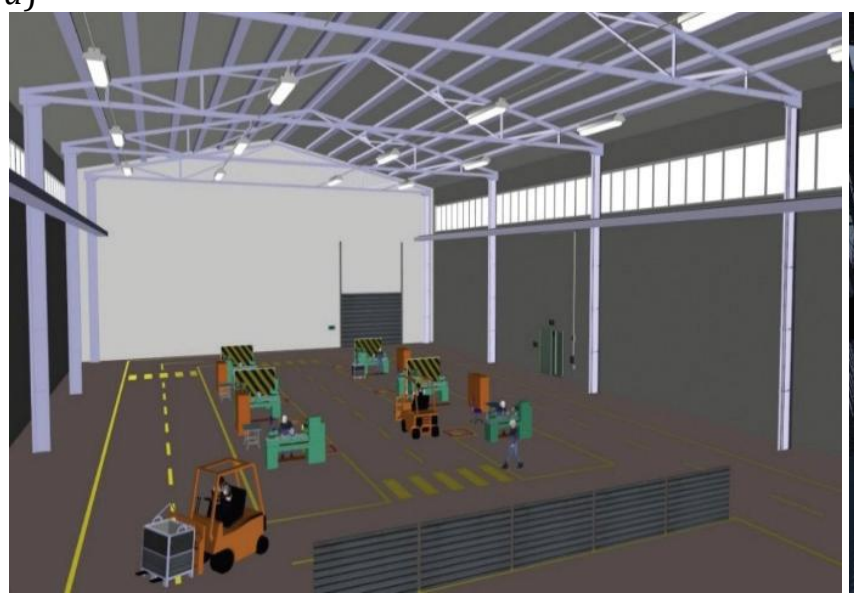

b)

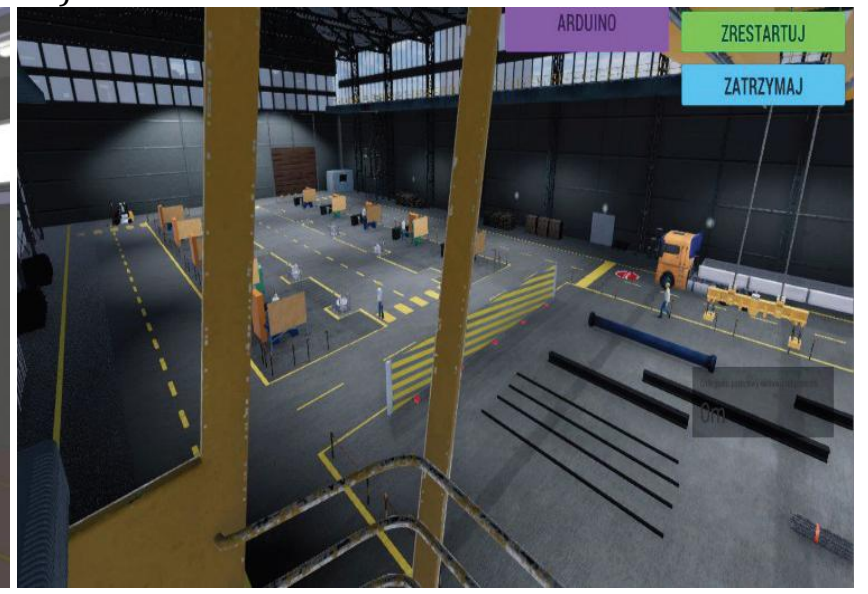

Fig. 1. Computer-generated image from a virtual environment: $a$ ) before modification and $b$ ) after modification (new software)

\section{Virtual environment}

In the newly developed virtual environment, many issues and solutions used in the software before modification were used [5, 6], e.g. dimensions of the virtual environment, method of operating the virtual crane (user-control interaction), interaction of the instructor in the simulation process, scenarios of tasks implemented during simulation, possibility of initiating the accident events as a result of a mistake made by the user and procedure of picking up and putting away baskets with the use of a hook. These issues have been newly programmed and supplemented with elements improving their functioning, such as:

- equipment objects were improved to increase realism of the environment (especially objects located near the crane operator),

- possibilities of picking, transporting and setting down the loads have been increased (e.g. picking up any load in the hall and putting down loads anywhere in the hall),

- hook assist has been improved not only when picking up the load, but also when setting down the load in the storage area,

- ability to display messages about an error, committed by the user, or accident event during the simulation has been added.

The software also includes new scenarios of tasks carried out during the simulation (e.g. transport of baskets for a truck or long bundles to workplaces) and new accident events (e.g. loss of load due to chain breaking) or dangerous situations that may have occurred during the simulation (e.g. too high or too low transported load, crossing the communication line, unauthorized transport of the load above the workplace).

\section{User communication with the environment}

The crane simulator user communication with the software takes place using the control panel, consisting of two panels located on both sides of the seat (fig. 2). As part of the modification, only analog joysticks were replaced with joysticks with a potentiometer. These joysticks have been properly programmed, i.e. a new algorithm has been developed to enable the signal to be picked up from the joysticks.

Movement of crane components (bridge, trolley traverse, cabs, traverses with a hook or electromagnet) is done by swinging the joystick lever (forward, backward or sideways). However, the speed of movement of these elements depends on the degree of swing of this stick (the greater the swing from zero position, the higher the speed of the object). Other controls and their interactions with crane objects have been reprogrammed, but their function has not changed. 


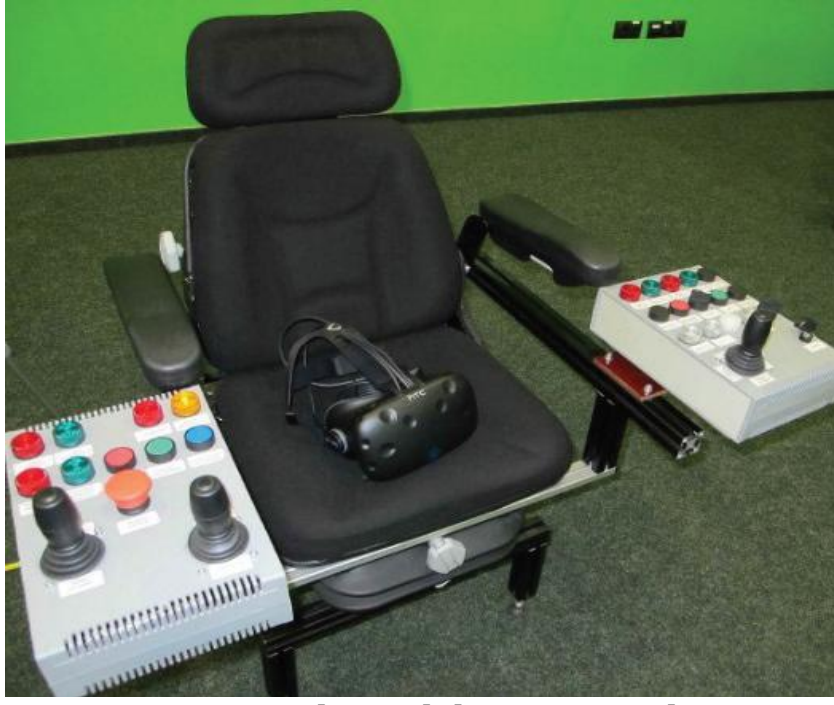

Fig. 2. Seat with a mobile crane simulator control panel

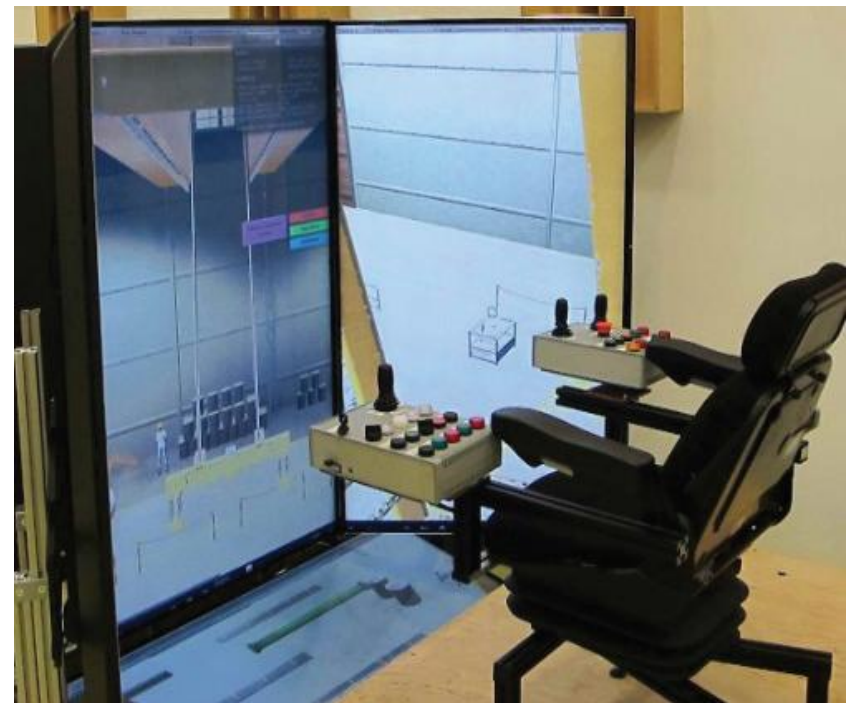

Fig. 3. Arrangement of screens in front of the crane simulator user in stationary version

\begin{tabular}{|c|c|c|c|c|c|c|c|c|c|}
\hline A & B & C & D & $\mathrm{E}$ & $\mathrm{F}$ & G & $\mathrm{H}$ & 1 & $\mathrm{~J}$ \\
\hline 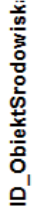 & 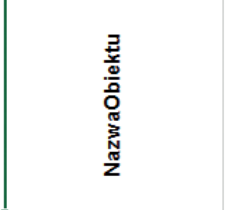 & 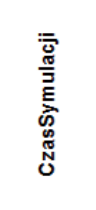 & \begin{tabular}{l}
$x_{1}$ \\
$\frac{\sigma}{5}$ \\
\multirow{N}{*}{} \\
0 \\
0 \\
0
\end{tabular} & 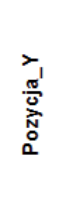 & $\begin{array}{l}N_{1} \\
\frac{\sigma}{0} \\
\text { స̃ } \\
0 \\
0\end{array}$ & 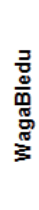 & 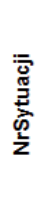 & 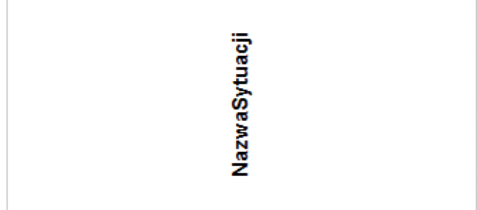 & 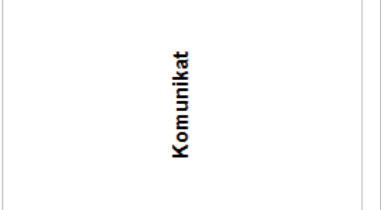 \\
\hline 43 & BelkaMetalowa1 & 00:00:46 & $-3,11$ & $-0,1$ & $-20,56$ & 1 & 1 & Niewlasciwa_Wysokosc_Ladunku_Nad_Podlozem & Zła wysokość ładunku \\
\hline 43 & BelkaMetalowa1 & $00: 00: 47$ & $-3,11$ & $-0,1$ & $-20,57$ & 1 & 1 & Niewlasciwa_Wysokosc_Ladunku_Nad_Podlozem & Zła wysokość ładunku \\
\hline 43 & BelkaMetalowa1 & $00: 00: 48$ & $-3,11$ & $-0,1$ & $-20,57$ & 1 & 1 & Niewlasciwa_Wysokosc_Ladunku_Nad_Podlozem & Zła wysokość ładunku \\
\hline 66 & Przegroda_magazyn & 00:01:03 & $-4,72$ & $-0,04$ & $-14,34$ & 2 & 3 & Uderzenie_Ladunkiem_W_Przeszkode & Uderzenie ładunkiem w Przegrodę \\
\hline 43 & BelkaMetalowa1 & 00:01:06 & $-3,33$ & $-0,52$ & $-14,91$ & 1 & 2 & Przekroczenie_Ciagu_Komunikacyjnego & Przekroczenie linii ciągu komunikacyjneg \\
\hline 63 & pracownik_na_pasach & 00:01:20 & $-4,6$ & $-0,05$ & $-10,27$ & 3 & 10 & Potracenie_Pracownika_Na_Pasach & Uderzenie ładunkiem w pracownika \\
\hline 62 & KolizyjnyWozekBoczny & 00:01:24 & $-6,89$ & $-0,05$ & $-13,18$ & 2 & 5 & Uderzenie_Ladunkiem_W_Wozek & Uderzenie ładunkiem w wózek widłowy \\
\hline 62 & KolizyjnyWozekBoczny & 00:01:25 & $-6,89$ & $-0,05$ & $-13,18$ & 2 & 5 & Uderzenie_Ladunkiem_W_Wozek & Uderzenie ładunkiem w wózek widłowy \\
\hline 43 & BelkaMetalowa1 & 00:01:33 & $-5,35$ & $-0,6$ & $-9,96$ & 1 & 1 & Niewlasciwa_Wysokosc_Ladunku_Nad_Podlozem & Zła wysokość ładunku \\
\hline 43 & BelkaMetalowa1 & 00:01:34 & $-5,34$ & $-0,96$ & $-9,58$ & 1 & 1 & Niewlasciwa_Wysokosc_Ladunku_Nad_Podlozem & Zła wysokość ładunku \\
\hline 43 & BelkaMetalowa1 & 00:01:35 & $-5,34$ & $-1,11$ & $-9,04$ & 1 & 1 & Niewlasciwa_Wysokosc_Ladunku_Nad_Podlozem & Zła wysokość ładunku \\
\hline 43 & BelkaMetalowa1 & 00:01:36 & $-5,34$ & $-1,57$ & $-8,57$ & 1 & 1 & Niewlasciwa_Wysokosc_Ladunku_Nad_Podlozem & Zła wysokość ładunku \\
\hline 43 & BelkaMetalowa1 & 00:01:37 & $-5,26$ & $-1,57$ & $-8,42$ & 1 & 1 & Niewlasciwa_Wysokosc_Ladunku_Nad_Podlozem & Zła wysokość ładunku \\
\hline 43 & BelkaMetalowa1 & 00:01:38 & $-4,65$ & $-1,6$ & $-8,42$ & 1 & 1 & Niewlasciwa_Wysokosc_Ladunku_Nad_Podlozem & Zła wysokość ładunku \\
\hline 43 & BelkaMetalowa1 & 00:01:39 & $-4,19$ & $-1,56$ & $-8,45$ & 1 & 1 & Niewlasciwa_Wysokosc_Ladunku_Nad_Podlozem & Zła wysokość ładunku \\
\hline 43 & BelkaMetalowa1 & 00:01:41 & $-3,65$ & $-1,65$ & $-8,45$ & 1 & 1 & Niewlasciwa_Wysokosc_Ladunku_Nad_Podlozem & Zła wysokość ładunku \\
\hline 43 & BelkaMetalowa1 & 00:01:42 & $-3,18$ & $-1,92$ & $-8,45$ & 1 & 1 & Niewlasciwa_Wysokosc_Ladunku_Nad_Podlozem & Zła wysokość ładunku \\
\hline 43 & BelkaMetalowa1 & 00:01:43 & $-2,63$ & $-2,13$ & $-8,45$ & 1 & 1 & Niewlasciwa_Wysokosc_Ladunku_Nad_Podlozem & Zła wysokość ładunku \\
\hline 43 & BelkaMetalowa1 & 00:01:44 & $-2,14$ & $-2,08$ & $-8,45$ & 1 & 1 & Niewlasciwa_Wysokosc_Ladunku_Nad_Podlozem & Zła wysokość ładunku \\
\hline 43 & BelkaMetalowa1 & 00:01:45 & $-2,06$ & $-2,15$ & $-8,45$ & 1 & 1 & Niewlasciwa_Wysokosc_Ladunku_Nad_Podlozem & Zła wysokość ładunku \\
\hline
\end{tabular}

Fig. 4. Fragment of the printout from the recorder of the simulation process covering data on dangerous situations

The new software allows for displaying the image from the simulation process on several monitors:

- on VR goggle screens (mobile crane simulator - fig. 2),

- on the instructor's screen,

- on four large screens of the stationary crane simulator (fig. 3).

The developed software is the same for the simulator in both versions. However, they differ in the way the image is displayed from the environment.

\section{Verification of the completed software}

Virtual environment software has been verified. To this end, a checklist was developed that covered issues related to:

- virtual environment,

- process of operating a virtual crane, including interaction between the control elements and their assigned functions,

- simulation scenarios (tasks) and dangerous situations that may occur during the simulation,

- recorder of the simulation process (fig. 4). 
This made it possible to determine whether all planned work had been carried out. The observed irregularities have been corrected.

\section{Conclusions}

The paper briefly introduces new software that is an important element of the modified simulator. To a large extent, the realism and smoothness of the simulation conducted by the user of the simulator depends on him and the objects made. In combination with a real control panel and VR goggles, this increases the sense of realism when the user is submerged in this environment. However, when displaying the images on large screens, it will allow the user to quickly identify with the environment, and thus - with the simulation.

The publication was prepared on the basis of results of the $4^{\text {th }}$ stage of the multiannual program "Improvement of safety and working conditions", financed in the years 2017-2019 in the scope of tasks of state services by the Ministry of Family, Labor and Social Policy.

Program coordinator: Central Institute for Labor Protection - National Research Institute.

\section{REFERENCES}

[1] Portouli V., Bekiaris E., Boets S., Henriksson P. “Comparative evaluation of training methods in improving drivers' understanding about the functionalities and potential limitations of ADAS". Proceedings of European Conference on Human Centred Design for Intelligent Transport Systems. France, 2008.

[2] "Virtual Reality Goes to School". New York Times, http://www.nytimes.com/2012/05/20/automobiles/virtual-reality-goes-to-school.html? $r=1$.

[3] Kalwasiński D. „Praktyczny test symulatora suwnicy w aspekcie symulacji wrażenia dotyku (Practical test of overhead crane simulator in the context of the sense of touch simulation)". Mechanik. 7 (2014): 285-294 [CD], http://www.mechanik.media.pl/archiwum.html.

[4] Saulewicz A., Myrcha K., Kalwasiński D. „Stosowanie wirtualnego symulatora podnośnikowego wózka widłowego do szkolenia operatorów (Application of virtual forklift simulator for the training of the operators)". X Szkoła Komputerowego Wspomagania Projektowania, Wytwarzania i Eksploatacji. WAT, Jurata, May 2006: 223-230.

[5] Kalwasiński D., Filipek D. „Narzędzie komputerowe do wspomagania szkoleń operatorów suwnic (Computer tool to support trainings of overhead crane operators)". Mechanik. 7 (2013): 297-306 [CD].

[6] Kalwasiński D. „Przenośny symulator suwnicy do wspomagania szkolenia operatorów suwnic koncepcja". Mechanik. 7 (2018): 609-611, DOI: https://doi.org/10.17814/mechanik.2018.7.99. 